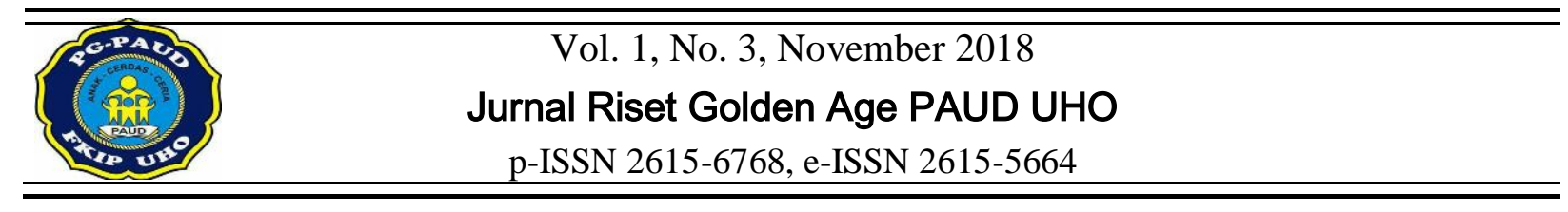

\title{
MENINGKATKAN KEMAMPUAN VISUAL-SPASIAL MELALUI KEGIATAN TEBAK GAMBAR MENGGUNAKAN MEDIA FLIP CHART
}

\author{
Nurna Ningsi ${ }^{1)}$, Salwiah ${ }^{1)}$ \\ ${ }^{1}$ Jurusan PG-PAUD, Universitas Halu Oleo. Jln. H.E.A Mokodompit, Kendari 93232, Indonesia.
}

\begin{abstract}
Abstrak
Tujuan dalam penelitian ini adalah untuk meningkatkan kemampuan visual-spasial anak melalui kegiatan tebak gambar menggunakan media flip chart di kelompok B2 TK Adi Permai Kendari. Penelitian ini dilaksanakan dalam dua siklus. Tahap-tahap dalam penelitian ini mengikuti prosedur penelitian tindakan kelas, yaitu: (1) perencanaan; (2) pelaksanaan; (3) pengamatan; (4) refleksi. Subjek dalam penelitian ini yaitu anak Kelompok B2 TK Adi Permai Kendari yang berjumlah 10 orang anak. Berdasarkan hasil analisis kemampuan visual-spasial anak melalui kegiatan tebak gambar menggunakan media flip chart menunjukkan bahwa terdapat peningkatan, hal ini dapat dibuktikan pada hasil sebelum tindakan diperoleh persentase sebesar $20 \%$ dan mengalami peningkatan pada siklus I yaitu sebesar $40 \%$ sehingga menjadi $60 \%$. Pada siklus II mengalami peningkatan sebesar $70 \%$ dari siklus I sehingga menjadi $90 \%$. Dengan demikian dapat disimpulkan bahwa kemampuan visualspasial di Kelompok B2 TK Adi Permai Kendari dapat ditingkatkan melalui kegiatan tebak gambar menggunakan media flip chart.
\end{abstract}

Kata Kunci: Kemampuan Visual-Spasial, Kegiatan Tebak Gambar, Media Flip Chart

\section{IMPROVING THE SPATIAL VISUAL ABILITY OF THE CHILDREN THROUGH PICTURE GUESSING ACTIVITIES USING FLIP CHART MEDIA}

\begin{abstract}
The research aims to increased of the spatial visual ability of the children through picture guessing activities using flip chart media in group B2 TK Adi Permai Kendari. This research is a classroom action research (PTK) conducted in two cycles. Stages in this research are planning, action, observation, and reflection. Subjects in this study were teachers and students in group $B_{2}$ TK Adi Permai Kendari amounted to 10 people. Based on the results of data analysis of teacher teaching activities on cycle 1 as much as 13 aspects obtained percentage of achievement of 69,23\% or 9 aspects achieved. Whereas in cycle II the results of teacher teaching activities increased to $92,30 \%$ or 12 aspects achieved. On learning activity of cycle 1 of 13 aspects obtained the percentage of achievement of $61,53 \%$ or 8 aspects achieved. While the learning activity of students cycle II has increased to $85 \%$ or 11 aspects achieved.Thus it can be concluded that the spatial visual ability of children in group b2 TK Adi Permai Kendari can be improved through the picture guess activities using flip chart media.
\end{abstract}

Keywords: Spatial, Image Guess Activity, And Flip Chart Media.

\section{PENDAHULUAN}

Undang-Undang No. 20 tahun 2003 tentang Sistem Pendidikan Nasional, disebutkan bahwa pendidikan adalah usaha sadar dan terencana untuk mewujudkan suasana belajar dan proses pembelajaran agar peserta didik secara aktif mengembangkan potensi dirinya untuk memiliki kekuatan spiritual keagamaan, pengendalian diri, kepribadian, kecerdasan, akhlak mulia, serta keterampilan yang diperlukan dirinya, masyarakat, bangsa, dan negara (Fadlillah, 2012: 65).

Froebel dalam Zaman (2008: 1.9) memandang anak sebagai individu yang kodratnya bersifat baik. Sifat yang buruk timbul karena kurangnya pendidikan atau pengertian yang dimiliki oleh anak tersebut. Setiap tahap 
perkembangan yang dialami oleh anak harus dipandang sebagai suatu kesatuan yang utuh. Anak memiliki potensi, dan potensi itu akan hilang jika tidak dibina dan dikembangkan.

Anak usia dini ialah anak yang berkisar antara usia 0-6 tahun yang memiliki pertumbuhan dan perkembangan yang luar biasa sehingga memunculkan berbagai keunikan pada dirinya (Fadillah, 2012: 19).

Para pakar pendidikan dalam Fadlillah, (2012: 65), pendidikan anak usia dini ialah suatu proses pembinaan tumbuh kembang anak usia lahir hingga enam tahun secara menyeluruh, yang mencakup aspek fisik dan non fisik, dengan memberikan rangsangan bagi perkembangan jasmani, rohani (moral dan spiritual), motorik, akal pikir, emosional, dan sosial yang tepat agar anak dapat tumbuh dan berkembang secara optimal.

UU No. 20 tahun 2003 tentang Sistem Pendidikan Nasional disebutkan bahwa pendidikan anak usia dini ialah suatu upaya pembinaan yang ditujukan kepada anak sejak lahir sampai dengan usia enam tahun yang dilakukan melalui pemberian rangsangan pendidikan untuk membantu pertumbuhan dan perkembangan jasmani dan rohani agar anak memiliki kesiapan dalam memasuki pendidikan lebih lanjut (Fadlillah, 2012: 66).

Visual spasial adalah salah satu bagian dari Multiple Intelligence yang terdiri dari delapan jenis kecerdasan yang berhubungan erat dengan kemampuan untuk memvisualisasikan gambar di dalam pikiran seseorang, atau untuk anak dimana dia berpikir dalam bentuk visualisasi dan gambar untuk memecahkan sesuatu masalah atau menemukan jawaban (Sujiono, 2008: 6.14).

Kemampuan visual spasial adalah kemampuan memahami bentuk, gambar atau pola, desain, warna-warna dan tekstur yang kita lihat dengan mata luar maupun yang dibayangkan di dalam kepala. Kesadaran spasial termasuk orientasi tubuh terhadap objek lain di dalam suatu ruang dan hubungan objek-objek tersebut satu sama lain. Anak-anak yang kuat dalam kemampuan ini sangat bagus dalam bermain puzzle, membaca peta, serta menemukan jalan di sekitar tempat baru. Mereka cenderung berpikir grafis, memiliki opini tentang warna, dan tekstur yang sangat menyenangkan. Menyukai tampilan, proses membayangkan, dan melihat dengan pikirannya (Kayvan, 2009: 1).
Anak yang memiliki kecerdasan visual spasial adalah seorang anak yang memiliki kemampuan untuk memvisualkan gambar di dalam pikirannya atau seorang anak yang dapat memecahkan suatu masalah atau menemukan suatu jawaban dengan memvisualkan bentuk atau gambar. Anak yang cerdas dibidang ini juga senang menikmati film atau foto dan mudah membaca peta, grafik atau diagram (Aisyah, 2008: 1.18).

Dharma (2013: 109) kecerdasan visualspasial merupakan kemampuan menerjemahkan atau memberi pendapat tentang segala sisi keruangan secara tepat dan dapat melakukan perubahan pada objek sebagai hasil dari perubahan objek tersebut.

Gamon dan Bragdon (2005: 236) kecerdasan visual spasial memiliki jenis kemampuan yang banyak dan berbeda-beda, dari menangkap secara detail hingga memahami pengaturan menjadi berbagai pola, sampai mencocokkan pola-pola tersebut ke dalam suatu landasan pengetahuan sehingga tahu apa yang harus dilakukan dengannya.

Kemampuan visual-spasial merupakan kemampuan yang berkaitan dengan kepekaan menangkap gradasi warna, kepekaan terhadap bentuk yang mirip dan berbeda, kesenangan membuat bangunan dari mainan, keakuratan mengenal arah, membuat bentuk dengan gambar dan jiplakan dan ruangan. Musfiroh (2008: 292).

Anak-anak yang cerdas dalam visual spasial peka terhadap bentuk dan peristiwa, mampu merekam/bentuk-bentuk tersebut dalam memorinya, serta memanggilnya kembali dalam bentuk melamun, menggambar atau menyatakan dalam kata-kata. Anak-anak mampu mendeskripsikan peristiwa dengan urutan-urutan yang jelas dan terperinci. Anak-anak yang cerdas visual spasial mampu melihat bentuk, warna, gambar, tekstur secara detil dan akurat (Musfiroh, 2008: 4.7).

Dari beberapa pendapat diatas dapat disimpulkan bahwa kemampuan visual spasial merupakan kemampuan atau kepekaan terhadap bentuk yang mirip dan berbeda ,menerjemahkan atau memberi pendapat sehingga tahu apa yang harus dilakukan dengannya.

Berdasarkan hasil observasi awal yang telah dilakukan di kelompok B2 TK Adi Permai kendari dalam meningkatkan kemampuan visual-spasial masih rendah, hal ini ditandai dengan kondisi pada saat melakukan observasi awal yang dilakukan peneliti di TK Adi Permai Kendari menunjukan bahwa dari 10 anak didik 
terdapat 2 anak atau sekitar $20 \%$ dengan kriteria memiliki kemampuan menebak gambar sehingga dapat dikatakan bahwa kemampuan menebak gambar anak belum mencapai tingkat perkembangan yang diharapkan yaitu kriteria Berkembang Sangat Baik (BSB) dan Berkembang Sesuai Harapan (BSH), selanjutnya sekitar 5 anak atau sekitar $50 \%$ yang Mulai Berkembang (MB) dimana anak sudah mulai mampu menebak gambar dari beberapa petunjuk dengan bantuan guru, dan sekitar 3 orang anak atau sekitar $30 \%$ yang Belum Berkembang (BB) atau pasif dimana anak belum dapat menebak gambar.

Rinayanti (2013: 3) mengemukakan kegiatan tebak gambar merupakan aktivitas bermain yang menyenangkan menggunakan media gambar berupa tiruan barang (orang, binatang, tumbuhan, dan sebagainya) yang tertuang diatas kertas, bermainnya dengan cara ditebak.

Kata "media" berasal dari Bahasa latin medius yang secara harfiah tengah, perantara atau pengantar. Gerlach dan Ely (1971:13) mengatakan bahwa media apabila dipahami secara garis besar adalah manusia, materi, atau kejadian yang membangun kondisi yang membuat siswa mampu memperoleh pengetahuan,keterampilan, atau sikap.

Flip chart adalah lembaran kertas yang berisikan bahan pelajaran yang tersusun rapi dan baik. Penggunaan ini adalah salah satu cara guru dalam menghemat waktunya untuk menulis di papan tulis. Lembaran kertas yang samaukurannya di jilid jadi satu secara baik agar lebih bersih. Penyajian dengan flip chart sangat menguntungkan untuk informasi visual seperti: (1) gambar-gambar, (2) huruf-huruf, (3) diagram, (4) bagan/chart dan (5) angka-angka (Arsyad Azhar 2003: 40).

Jadi media flip chart merupakan media dalam bentuk lembaran kertas bolak balik yang berbentuk seperti kalender yang berisi bahan pengembangan materi yang berfungsi menghemat waktu guru untuk menulis di papan tulis.

\section{METODE}

Jenis penelitian yang digunakan pada penelitian ini oleh peneliti adalah Penelitian Tindakan Kelas (PTK). Igak Wardhani dan Kusmaya Wihardit (2010: 1.4) bahwa penelitian tindakan kelas merupakan suatu penelitian pula, yang dengan sendirinya mempunyai berbagai aturan dan langkah yang harus diikuti. Penelitian tindakan kelas merupakan terjemahan dari Classroom Action Research, yaitu Action Research yang dilakukan di kelas. Penelitian tindakan kelas adalah penelitian yang dilakukan oleh guru di dalam kelasnya sendiri melalui refleksi diri, dengan tujuan untuk memperbaiki kinerjanya sebagai guru, sehingga hasil belajar anak didik menjadi meningkat.

Penelitian ini dilaksanakan bulan Februari di Kelompok B2 Tk Adi Permai Kendari 2017/2018. Subjek dalam penelitian ini yaitu anak Kelompok B2 TK Adi Permai Kendari yang berjumlah 2 orang anak perempuan dan 8 anak laki-laki. Objek yang akan diteliti adalah meningkatkan kemampuan visual-spasial melalui kegiatan tebak gambar menggunakan media flip chart.

Faktor yang diteliti dan diamati dalam penelitian tindakan kelas ini adalah sebagai berikut: 1) Faktor anak didik, 2) Faktor guru, 3) Hasil belajar anak tentang meningkatkan kemampuan visual spasial melalui media flip chart.

Penelitian ini direncanakan dua siklus dan masing-masing siklus terdiri atas empat kali pertemuan. Secara umum, terdapat empat langkah dalam melakukan PTK, yaitu (1) perencanaan; (2) pelaksanaan; (3) pengamatan; (4) refleksi (Arikunto, 2006 dalam Suyadi, 2010: 49).

Teknik pengumpulan data yang dilakukan pada penelitian ini dengan menggunakan cara pengamatan/observasi, wawancara, dan dokumentasi. 1) Pengamatan/observasi adalah suatu teknik yang dapat dilakukan guru untuk mendapatkan berbagai informasi atau data tentang perkembangan dan permasalahan anak. Melalui pengamatan, guru dapat mengetahui bagaimana perubahan yang terjadi pada anak dalam satu waktu tertentu, 2). Wawancara dilakukan dengan berkomunikasi kepada guru dan kepala sekolah. 3) Dokumentasi yang digunakan dalam penelitian ini adalah mengambil data anak berupa hasil karya anak pada saat melakukan proses pembelajaran di sekolah dan foto-foto dalam proses pembelajaran berlangsung sebagai data yang mendukung untuk dianalisis.

Teknik analisis data yang digunakan dalam penelitian ini disesuaikan dengan teknik penilaian di Taman Kanak-kanak yaitu dengan menggunakan tanda sebagai berikut: * = Belum Berkembang (BB), $* *=$ Mulai Berkembang $(\mathrm{MB}),{ }^{* * *}=$ Berkembang Sesuai Harapan 
$(\mathrm{BSH}), * * * *=$ Berkembang Sangat Baik (BSB) (Depdiknas, 2004: 26).

Penelitian tindakan kelas ini dikatakan berhasil apabila anak secara perorangan dan klasikal melaksanakan rencana kegiatan pembelajaran dengan jumlah ketuntasan belajar sudah mencapai nilai $75 \%$ dari jumlah anak Kelompok B TK Wulele Sanggula II Kota Kendari mencapai nilai Berkembang Sesuai Harapan (BSH) dan Berkembang Sangat Baik (BSB) sehingga dikatakan pelaksanaan pembelajaran berhasil.

\section{HASIL DAN PEMBAHASAN}

Hasil penelitian ini dilaksanakan Kelompok $B_{2}$ TK Adi Permai Kendari. Kegiatan ini dilaksanakan selama dua minggu, yaitu 05 Februari 2018 sampai dengan 14 Februari 2018. Penelitian ini, dilaksanakan dalam dua siklus, dimana masing-masing siklus terdiri dari 3 kali pertemuan, dan masing-masing pertemuan menerapkan RPPH dan RPPM.

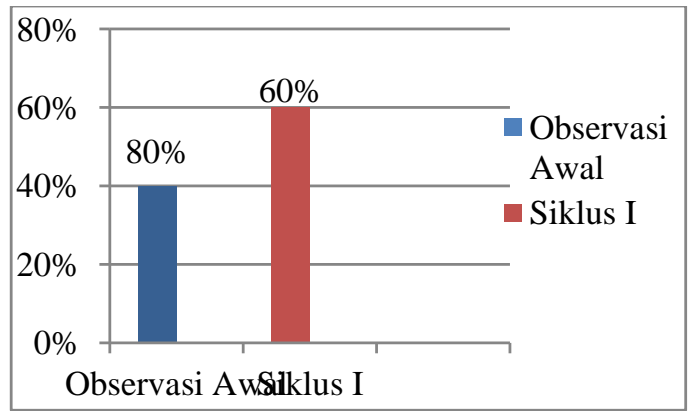

Gambar 1. Histogram Hasil Analisis Kemampuan visual-spasial Anak siklus I

Berdasarkan hasil evaluasi tersebut, sebagian besar anak sudah dapat melaksanakan kegiatan dengan baik, namun belum mencapai indikator kinerja yaitu $\geq 85 \%$ jika anak memperoleh nilai Berkembang Sesuai Harapan (BSH) dan Berkembang Sangat Baik (BSB).

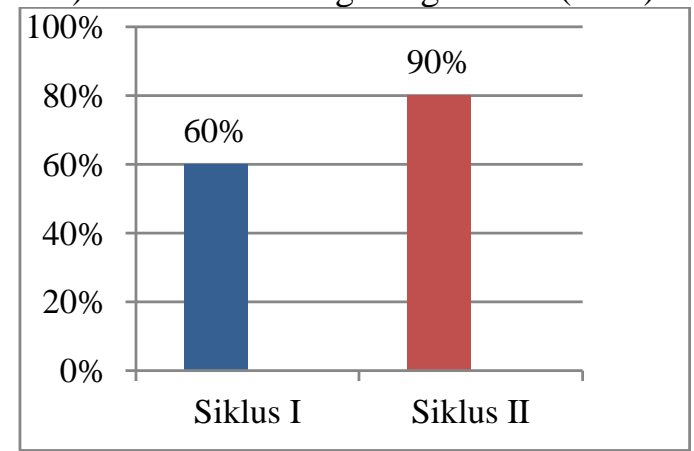

Gambar 2. Histogram Hasil Analisis Kemampuan visual-spasial Anak Siklus I dan Siklus II
Berdasarkan perolehan nilai anak didik yang ditampilkan pada tabel 4.3 dan tabel 4.6, dapat dinyatakan bahwa program kegiatan dalam meningkatkan kemampuan visual-spasial anak melalui kegiatan tebak gambar menggunakan media flip chart di kelompok B2 TK Adi Permai Kendari secara klasikal pada siklus II mencapai tingkat keberhasilan sebesar 90\% yang dicapai oleh 9 orang anak didik, dimana 5 orang anak memperoleh nilai bintang (****) atau berkembang Sangat Baik (BSB) dengan persentase $50 \%$ dan 4 orang anak memperoleh nilai bintang $(* * *)$ atau Berkembang Sesuai Harapan (BSH) dengan persentase $40 \%$.

Kondisi kemampuan awal anak dalam proses kegiatan tebak gambar menggunakan media flip chart belum berkembang dengan baik dengan hasil persentase anak yang memperoleh bintang (****) dan bintang (***) atau Berkembang Sesuai Harapan (BSH) dan Berkembang Sangat Baik (BSB) hanya mencapai $20 \%$ atau 2 orang anak. Hasil dari observasi awal apabila dibandingkan dengan pelaksanaan siklus I terlihat adanya peningkatan sebanyak 6 anak dengan persentase sebesar $60 \%$ karena aspek pelaksanaan proses pembelajaran telah direvisi sehingga menghasil produk aktivitas belajar. Sedangkan siklus II mengalami peningkatan saat proses pelaksanaan pembelajaran sebesar $90 \%$ dari 9 anak pada siklus II, hasil belajar telah mencapai indikator kinerja yang ditetapkan yaitu $\geq 85 \%$, sehingga tidak perlu dilakukan suatu perbaikan pada siklus selanjutnya karena indikator kinerja yang diharapkan telah tercapai.

Hasil yang diperoleh dalam pelaksanaan siklus II ternyata mengalami peningkatan dari $60 \%$ siklus I, mengalami peningkatan pada siklus II menjadi $90 \%$ dengan rincian 5 anak yang memperoleh bintang (****) atau Berkembang Sangat Baik (BSB), dan 4 orang anak yang memperoleh bintang (***) atau Berkembang Sesuai Harapan (BSH) dari hasil analisis keberhasilan tindakan secara klasikal

\section{KESIMPULAN DAN SARAN}

\section{Kesimpulan}

Berdasarkan hasil penelitian yang dilakukan selama dua siklus dapat disimpulkan bahwakemampuanvisual-spasial Anak dapat ditingkatkan melalui kegiatan tebak gambar menggunakan media Flip chartdi Kelompok B2 
TK Adi Permai Kendari dengan jumlah anak didik 10 orang, yang terdiri dari 8 orang anak laki-laki dan 2 orang anak perempuan mengalami peningkatan. Hal ini di tunjukan dari adanya peningkatan pada kegiatan tebak gambar menggunakan media Flip Chart dengan perolehan presentase aktivitas belajar anak didik meningkat. Berdasarkan analisis data hasil observasi aktivitas mengajar guru pada siklus I diperoleh dari 13 aspek yang diamati hanya 9 aspek yang dicapai oleh guru dengan diperoleh persentase ketercapaian sebesar 69,23\%, sedangkan hasil belajar anak didik pada siklus I dari 13 aspek yang diamati hanya 8 aspek yang dicapai oleh anak dengan diperoleh persentase ketercapaian sebesar 61,53\%. Pada siklus II, persentase ketercapaian aktivitas mengajar guru mengalami peningkatan menjadi 92.30, sedangkan persentase ketercapaian aktivitas belajar anak didik juga mengalami peningkatan menjadi $85 \%$. Dengan demikian dapat disimpulkan bahwa kemampuan visual-spasial anak dapat ditingkatkan melalui kegiatan tebak gambar menggunakan media flip chart di Kelompok B2 TKAdi Permai Kendari.

\section{Saran}

Peneliti menyarankan hal-hal diantaranya: 1). Bagi guru Sebaiknya guru menggunakan kegiatan tebak gambar menggunakan media flip chart sebagai salah satu alternatif untuk meningkatkan kemampuan visual-spasial. 2) Bagi sekolah Memberikan dan menyediakan fasilitas yang mendukung kegiatan tebak gambar menggunakan media flip chart untuk meningkatkan kemampuan visual-spasial anak. 3). Bagi peneliti selanjutnya mengenai peningkatan kemampuan visual-spasial anak melalui kegiatan tebak gambar menggunakan media flip chart, masih banyak kekurang dan jauh dari sempurna. Oleh karena itu, menjadi motivasi bagi peneliti selanjutnya untuk melengkapi penelitian ini, yaitu dengan variasi yang lebih beragam, sehingga lebih meningkatkan visual-spasial anak dapat ditingkatkan melalui kegiatan tebak ggambar menggunakan media flip chartsebagai pembelajaran pada anak usia dini.

\section{DAFTAR PUSTAKA}

Aisyah, Siti. 2010. Perkembangan dan Konsep Dasar Pengembangan Anak Usia Dini. Jakarta: Universitas Terbuka.
Arikunto, Suharsimi. 2014. Penelitian Tindakan Kelas. Jakarta: PT Bumi Aksara.

Arsyad, Azhar. 2011. Media Pembelajaran. Jakarta: Raja Grafindo Persada.

Fadlillah, Muhammad. 2012. Desain Pembelajaran PAUD: Panduan untuk Pendidik, Mahasiswa, \& Pengelola Pendidikan Anak Usia Dini. Tinjauan Teoretik \& Praktik. Jogjakarta: Ar-Ruzz Media.

Gamon, David dan Allen D.Bragdon. 2005. Cara Baru Mengasah Otak dengan Asyik. Bandung: Kaifa.

Gerlach, V.G. dan Ely, D.P. 1971. Teaching and Media. A Systematic Approach. Englewood Cliffs: Prentice Hall, Inc.

Kayvan, Umi. 2009. 57 Permainan Kreatif untuk Mencerdaskan Anak. Jakarta: Mediakita.

Musfiroh, Takdiroatun. 2008. Pengembangan Kecerdasan Majemuk. Jakarta: Universitas Terbuka.

Rinayanti. 2013. Upaya Guru dalam Melatih Kemampuan Berpikir Kritis Anak Usia Dini melalui Permainan Tebak Gambar di TK Mekarsari Kecamatan Rasau Jaya Pontianak. Jurnal Pendidikan dan Pembelajaran

Sujiono, Yuliani Nurani, Dkk. 2008. Metode Pengembangan Kognitif. Jakarta: Universitas Terbuka.

Suyadi. 2010. Panduan Penelitian Tindakan Kelas: Buku Panduan Wajib bagi Para Pendidik. Banguntapan Jogjakarta: DIVA Press.

Wardhani, Igak \& Wihardit, Kusmaya. 2008. Penelitian Tindakan Kelas. Jakarta: Universitas Terbuka. 